\title{
Comprehensive Methods of Evaluation and Project Efficiency Account
}

\author{
Anna Kaczorowska \\ University of Lodz \\ Faculty of Management, \\ Department of Computer Science \\ ul. Matejki 22/26, 90-237 Lodz, \\ Poland \\ Email: annak@wzmail.uni.lodz.pl
}

\author{
Jolanta Słoniec \\ Lublin University of Technology \\ Faculty of Management, \\ Department of Enterprise \\ Organization, Nadbystrzycka Str., \\ 38, 20-618 Lublin, Poland \\ Email: j.sloniec@pollub.pl
}

\author{
Sabina Motyka \\ Cracow University of Technology \\ Faculty of Mechanical, Department \\ of Manufacturing Processes, \\ M6 Institute, al. Jana Pawła II 37, \\ 31-864 Cracow, Poland \\ Email: motyka@mech.pk.edu.pl
}

\begin{abstract}
Project management is one of the main areas of contemporary organization management. This article is aimed at analysis of existing tools of project assessment - mainly comprehensive methods, but also partial techniques - and referring them to undertakings efficiency calculation which comprises cost-effectiveness evaluation, risk analysis, and investment decision taking. Business case (BC), as one of the comprehensive methods of project assessment, is simultaneously the main subject in PRINCE2 (PRoject IN Controlled Environments). It is for this reason that the case study for $\mathrm{BC}$ is based on this recognised method of project management. This article contains also the proposals of solutions of discerned problems within project assessment.
\end{abstract}

\section{INTRODUCTION}

$\mathrm{S}$ ITUATIONS of assessment occurring in project management are largely diversified and require the use of appropriate methods adjusted to each of them. A correctly and reliably carried out assessment will support the manager in taking conscious decisions as to the projects which should be invested in.

Speaking about assessment we usually mean definition, estimation, and valuation of something. Assessment in relation to projects means the ,functional value, i.e. the whole of the project features determining its ability to meet specific needs" [9].

Choosing any tool for project assessment we expect that it will first ascribe to them specific parameters of assessment, second - classify projects, third - enable a comparison of projects, and fourth - enable following the progress of project works.

Each project should cause positive effects consisting in generation of profits and negative effects related to incurring of inputs to obtain new values. Therefore, the main components of project assessment are inputs and profits. Such perspective combines the most important aspects of project assessment, i.e. assessment of its result and assessment of its course [2].

The final results of the projects are always an outcome of inputs and profits. The inputs are treated comprehensively, i.e. as the consumption of all sorts of means - both countable and such which cannot be expressed in monetary units.
Benefits are understood as various positive effects of projects and may be nominal, tangible and intangible.

A summary evaluation independent of the type of the project is the total result which is a difference of benefits and inputs. If the benefits and inputs may be expressed monetarily, the total result of assessment is profit. Many techniques have been worked out for this case. They are called the investment account techniques, because they are used in assessment of investment undertakings. The following techniques of investment undertakings assessment may be singled out:

- simple techniques of absolute assessment - e.g. payback period (PP), accounting rate of return (ARR),

- discount techniques of absolute evaluation - e.g. gross present value (GPV), internal rate of return (IRR), profitability ratio (PR), techniques of discounted period of return and their modifications [14],

- techniques of relative efficiency account [14].

Commercial projects are assessed using the monetary techniques of assessment:

- simple - such as : simple rate of return (return on equity ROE, return on investment - ROI), PP, ARR,

- comprehensive (discount) - discounted payback period (DPP), net present value (NPV), IRR, modified internal rate of return (MIRR) [14]-[15]-[16].

The project in which only inputs may be expressed monetarily requires different techniques of assessment, such as: cost benefit analysis and cost effectiveness analysis. The advantage of those techniques is shown in points as a result of multi-dimensional assessment in points. When in the cost benefit analysis the benefit estimated in points includes the probability of its occurrence, it becomes a cost effectiveness analysis.

When neither benefits nor inputs may be expressed monetarily, the total result of assessment is profitability. In this case it consists of their determination by multi-criterial assessment in points and comparison of the obtained values, e.g. as the quotient of the value of profits in points and the point-wise value of input. 
If the profit may be expressed monetarily, and the input is not considered (little importance, problems with estimation), the projects are assessed according to the account of incomes. Otherwise, when benefits are not considered and the input may be estimated in monetary units, assessment is based on the costs account.

When inputs can be determined neither monetarily nor non-monetarily, assessment is made as an analysis of the project's functional value or as analysis of effectiveness.

Insignificance of benefits during project assessment and possibility of only non-monetary expression of input cause the need of the point assessment of the input value.

Taking an investment decision within the project efficiency account may refer to [1]: a single project (absolute or time-related decision), variants of the project or projects competing for common limited resources, including the capital (relative or portfolio decision).

\section{CLASSIFICATIONS OF PROJECT ASSESSMENT METHODS}

The project assessment methods constitute an extensive collection where various groups may be singled out due to: application area, scope of problems, details of recommendations.

Table I presents classifications of project assessment methods, including the mentioned items as the division criteria.

TABLE I.

CLASSIFICATIONS OF PROJECT ASSESSMENT METHODS

\begin{tabular}{|c|c|}
\hline \multicolumn{2}{|c|}{ Classification criterion of assessment methods } \\
\hline \multicolumn{2}{|c|}{ APPLICATION AREA } \\
\hline Universal & Special \\
\hline DETAILS of RECOMMENDATIONS \\
\hline General & Detailed \\
\hline \multicolumn{2}{|c|}{ SCOPE of PROBLEMS } \\
\hline Comprehensive & Partial \\
\hline
\end{tabular}

In project assessment both universal methods (usable in assessments of any type) and special methods (usable in project management assessments, e.g. the Earned Value method - assessment of project implementation advancement) may be applied.

Methods containing general recommendations are considered as general methods of project assessment, whereas those which present recommendations precisely and accurately are determined as detailed ones.

Partial methods refer to partial processes and problems within the project assessment. They are called techniques and may be used in various stages of project management and in different phases of its life cycle.

Comprehensive methods comprise with their recommendations the whole process of project assessment. These methods of project assessment comprise: feasibility studies (hereinafter referred to as FS), business plans of the project, business cases (BC), and cost benefit analysis. The characteristics which should describe the methods to make them considered as comprehensive were presented in Table II.

TABLE II.

SPECIFICITY OF COMPREHENSIVE METHODS OF PROJECT EVALUATION

\begin{tabular}{|c|c|}
\hline Characteristics & Description of characteristic \\
\hline Completeness & $\begin{array}{l}\text { Detailed description of all issues } \\
\text { important for project estimation }\end{array}$ \\
\hline Perspectiveness & $\begin{array}{l}\text { Including into the description the } \\
\text { whole period of preparation, } \\
\text { performance and use of the project }\end{array}$ \\
\hline $\begin{array}{l}\text { Accuracy of } \\
\text { assumptions and } \\
\text { reliability of data }\end{array}$ & $\begin{array}{l}\text { Data are derived from trustworthy } \\
\text { sources and enabling the } \\
\text { preparation of reliable evaluation } \\
\text { results }\end{array}$ \\
\hline Internal compliance & $\begin{array}{l}\text { Subordination of individual } \\
\text { components to assumptions and } \\
\text { their non-contradiction }\end{array}$ \\
\hline Reality & $\begin{array}{l}\text { Reality-consistent presentation of } \\
\text { circumstances affecting } \\
\text { implementation of the project and } \\
\text { its solutions }\end{array}$ \\
\hline Variants & $\begin{array}{l}\text { Analysis of possible solutions in } \\
\text { several variants }\end{array}$ \\
\hline Flexibility & $\begin{array}{l}\text { Predispositions to introduce } \\
\text { amendments, changes and } \\
\text { supplements connected with inflow } \\
\text { of new information }\end{array}$ \\
\hline Operations & $\begin{array}{l}\text { Possibility to translate the method } \\
\text { description into concrete decisions }\end{array}$ \\
\hline Comprehensibility & $\begin{array}{l}\text { Adjustment of the contents, volume } \\
\text { and form of method description to } \\
\text { recipients' needs and requirements }\end{array}$ \\
\hline Communicativeness & $\begin{array}{l}\text { Explicit and comprehensible } \\
\text { transmission of the contents of the } \\
\text { method to all potential users }\end{array}$ \\
\hline $\begin{array}{l}\text { Extensiveness of the } \\
\text { stage of determining the } \\
\text { assessment objectives }\end{array}$ & $\begin{array}{l}\text { In case of FS and BC this stage } \\
\text { consists even in examining the } \\
\text { circumstances of future functioning } \\
\text { of assessment objects and designing } \\
\text { them according to these conditions }\end{array}$ \\
\hline
\end{tabular}

All comprehensive methods of the projects are in many elements similar to each other but due to the differences occurring between them they were discussed in separate parts of the article.

\section{FEASIBILITY STUDY}

\section{A. Description of the method}

Feasibility study is defined as:

- "A short, preliminary study undertaken to assess the validity of a full-scale project" [17],

- formal study to determine the probability of success of a particular project or achieve a particular result [18].

"The purpose of the feasibility study tool is to identify whether the concept of a project is viable." The study contents seven parts: "executive summary, background information, description of current situation/problem, description of proposed idea, project timelines, feasibility review board, go/no-go decision. Dow mentions "types of 
feasibility studies used today: schedule: analyze how long it will take a project or process to complete and what go/no-go decision point will be; organizational: analyze what the impacts would be on costs and resources if the company decides to reorganize their current resources base; legal: analyze whether it is worth pursuing a particular litigation; technical: analyze if a technical concept will work within the current environment; cultural: analyze whether offshore teams and onshore teams can communicate and effectively execute a project; construction: analyze if it is cost effective to construct a building, based on the height and location; environmental: analyze whether the environmental conditions at the particular location are suitable" [19].

The methodology of creating feasibility study is similar to the methodology of problem solving. It has also much in common with the methods of scientific work, and it consists of the following parts: precise problem definition, project limits indication, identify the characteristics and functions of a good solution to the problem, description of alternative solutions, ranking of alternative solutions, conclusions from the analysis of alternative solutions and recommendation the best solution, determine the timing and expected costs of the project [20].

FS is one of the complex methods of project evaluation and it is used to check to what extent, by what means and at what time the project can be realized. The method consists of five parts: technology and system feasibility, economic feasibility, legal feasibility, operational feasibility, schedule feasibility. It should be also taken into account: market and real estate feasibility, recourse feasibility, cultural feasibility [21].

The number of parts of the method is different depending on the author (from five to eight), and each of them could be used in some types of projects.

By Newton "feasibility is the review of the project in more detail" [22]. This method may include activities such as technical tests, market research and assessment of the impact of the project on the organization. After the completion of the feasibility study the cost, duration and the outcome of the project should be known.

"Feasibility studies (...) reduce the risk of incorrectly accepting or rejecting a project. Although it can be considered as a stage in a project's lifecycle. (...) Feasibility studies have a cost and absorb resources, so in turn they must be reviewed and prioritized. (...) The decision whether to undertake a feasibility study is a trade-off between the cost and the value of the information determined [22].

The feasibility study should be carried out to provide the information needed to determine whether a project should proceed. It includes: technical feasibility to determine whether a project will successfully create the expected deliverables, commercial feasibility to determine whether a project will achieve its business case, market feasibility (usually in the case of new products) to determine whether the business's customers will buy the product, organizational feasibility to determine the operational impact of making the change resulting from a project successfully, exploring requirements and designs to produce more accurate plans, costs and resource profiles for a project, exploring project options.

Feasibility studies allow you to determine beyond any doubt whether the problem can be solved at all, or whether it is possible to use the opportunity. Usually they are created for the management board. Feasibility study consists of eight parts: abstract, defined business problem or business opportunity, requirements and purpose of the study, description of evaluated options, assumptions made in the study, users affected by introductions changes, financial commitments, recommended procedures [23].

As you can see there are a lot of definitions of feasibility studies, but the most important characteristics of this study is that it is a short, complex, preliminary study, made for the management board, undertaken to assess the validity of a project.

\section{B. Reference to project efficiency}

The efficiency of the projects in relation to the projects is defined as a relationship between total expenditure and the effects and the evaluation of the results concerning their utility, which answers the question of whether the information needs of users of information system have been met. Three main streams of IT projects evaluation have been classified [24]:

- technical and functional trend, which assumes that the effects of investment in information systems are shortterm and have no connection with the business strategy; assumptions of this trend are correct in relation to simple automation systems,

- economic and financial trend, which treats IT investments as aimed at increasing business efficiency or extend it; the evaluation moves here from the project treated in isolation to the quality of its products or services provided to internal and external customers; techniques assessments of projects derived from the management of value may be used herein among others,

- trend of possible interpretations, resulting from the specificity of investments; it takes into account the entire life cycle of the project, including the expenditure and benefits in its course, and the emphasis is on decisionmaking context in which the project exists.

Table III contains a comparison of these trends [25].

TABLE III.

COMPARISON TRENDS OF EVALUATION IT PROJECTS

\begin{tabular}{|l|l|l|l|}
\hline \multirow{2}{*}{ Dimension } & \multicolumn{3}{|c|}{ Trend } \\
\cline { 2 - 4 } & $\begin{array}{l}\text { Technical and } \\
\text { functional }\end{array}$ & $\begin{array}{l}\text { Economic and } \\
\text { financial }\end{array}$ & $\begin{array}{l}\text { Possible } \\
\text { interpretations }\end{array}$ \\
\hline \multirow{3}{*}{ Objective } & $\begin{array}{l}\text { Technical } \\
\text { efficiency, IT }\end{array}$ & $\begin{array}{l}\text { Quality and } \\
\text { rate of } \\
\text { resource } \\
\text { utilization the } \\
\text { control, cost of } \\
\text { system and the }\end{array}$ & $\begin{array}{l}\text { Solutions } \\
\text { sensitive to } \\
\text { context, learning } \\
\text { of organization }\end{array}$ \\
& the system & $\begin{array}{l}\text { effects of its } \\
\text { introduction }\end{array}$ & ofing \\
\hline
\end{tabular}




\begin{tabular}{|l|l|l|l|}
\hline $\begin{array}{l}\text { Object of the } \\
\text { evaluation, } \\
\text { used criteria }\end{array}$ & $\begin{array}{l}\text { IT system, } \\
\text { automation, } \\
\text { cost reduction }\end{array}$ & $\begin{array}{l}\text { Product of IT } \\
\text { system: } \\
\text { productivity, } \\
\text { enterprise } \\
\text { value, user } \\
\text { satisfaction }\end{array}$ & $\begin{array}{l}\text { Wallets of IT } \\
\text { systems, } \\
\text { measurement of } \\
\text { indirect effects }\end{array}$ \\
\hline $\begin{array}{l}\text { Time } \\
\text { horizon }\end{array}$ & $\begin{array}{l}\text { Ex-ante and } \\
\text { ex-post } \\
\text { investment, } \\
\text { system } \\
\text { lifecycle }\end{array}$ & $\begin{array}{l}\text { Ex-ante and ex- } \\
\text { post in relation } \\
\text { to the life cycle } \\
\text { of the system }\end{array}$ & $\begin{array}{l}\text { Perpetual effects } \\
\text { management }\end{array}$ \\
\hline $\begin{array}{l}\text { The role of } \\
\text { people in the } \\
\text { evaluation } \\
\text { process }\end{array}$ & $\begin{array}{l}\text { IT experts } \\
\text { IT experts, } \\
\text { financial } \\
\text { managers }\end{array}$ & $\begin{array}{l}\text { participants in } \\
\text { the evaluation } \\
\text { process, internal } \\
\text { and external } \\
\text { customer of IT } \\
\text { services }\end{array}$ \\
\hline $\begin{array}{l}\text { Used } \\
\text { methodology }\end{array}$ & $\begin{array}{l}\text { quality and } \\
\text { costs }\end{array}$ & $\begin{array}{l}\text { Orientation to } \\
\text { economics, } \\
\text { financial and } \\
\text { behavioural }\end{array}$ & $\begin{array}{l}\text { Development of } \\
\text { meta- } \\
\text { methodology }\end{array}$ \\
\hline Assumptions & Cost efficiency & $\begin{array}{l}\text { System } \\
\text { efficiency }\end{array}$ & $\begin{array}{l}\text { Understanding } \\
\text { the problem }\end{array}$ \\
\hline
\end{tabular}

Currently multi-criteria projects evaluation methods are often used. They include [26]: scoring method, AHP method, PROMETHEE-II method.

Scoring method is the most frequently used multi-criterial method. It allows you to list the ranking of decision variants based on the score, which projects received in each category. There are different versions of the method, simple and complex. Simple version assumes that each criterion has the same maximum number of points. The final evaluation of variant is the sum of all the points awarded in all criteria. The complex method involves the granting of weight to each criterion due to its validity. Criteria can be also described as linear functions. An important assumption of the method is that the criteria are independent in terms of preferences, that means the one criterion does not depend on the value which takes the other one. A similar to scoring method is the SMART method (Simple Multi-Attribute Ranking Technique). It assumes the existence of an additive utility function, which can be described as non-linear function.

AHP method (Analytic Hierarchy Process), like the scoring method, involves weighing of criteria. Rating variant is the sum of ratings of individual criteria. In the method, decision maker deliver his/her opinion on relations between variants. The opinion is expressed verbally using a ninepoint scale for comparison. Ranking decision variants in relation to the criteria is calculated as a weighted average of the ratings which options have obtained due to the individual criteria. A limitation of the use of method is that the project must have a small number of variants and variants cannot be dependent on each other. Development of AHP method taking into account the linkages between criteria and feedback relationships between the variants and the criteria is the ANP method (Analytic Network Process).

In the PROMETHEE-II method (Preference Ranking Organization METHod for Enrichment of Evaluation) it is built variants ranking decision as in the AHP method. But the options are compared automatically based on the information provided by the decision maker. The decision maker determines the value of the difference between the variants that one variant was the preferred relative to the other.

Each method is applicable to multi-criteria evaluation of projects in certain specific cases.

\section{Case study}

In the literature it is described the problem of selecting IT project using AHP method [27]. The company is to be implemented management support system and owners have to choose contractor for the implementation of IT system among three alternative projects. Evaluation of projects is based on the methodology proposed by Parker [28, 29].

The criteria consist of three factors and they make up to maintain the company's competitiveness: the financial contribution (the value to achieve, acceleration, restructuring, innovation, efficiency, productivity, NPV, IRR), support projects providing management information (the reaction of competitors, compliance with the strategy and structure, organizational risk), technological requirements (technological risk, providing innovation, compatibility with existing IT, uncertainty of the construction project).

Assessment of the criteria for each of the remaining criteria is based on a scale proposed by Saaty [30].

TABLE IV.

GRADING SCALE IN THE AHP METHOD

\begin{tabular}{|l|l|c|}
\hline Definition & Factor \\
\hline Equally important & $\begin{array}{l}\text { Activities contribute identically to } \\
\text { aim }\end{array}$ & 1 \\
\hline $\begin{array}{l}\text { Slightly more } \\
\text { important or preferred }\end{array}$ & $\begin{array}{l}\text { Experience and judgment slightly } \\
\text { favours one activity over the other }\end{array}$ & 3 \\
\hline $\begin{array}{l}\text { More important or } \\
\text { strongly preferred }\end{array}$ & $\begin{array}{l}\text { Experience and judgment strongly } \\
\text { favours one activity over the other }\end{array}$ & 5 \\
\hline $\begin{array}{l}\text { More important or } \\
\text { very strongly preferred }\end{array}$ & $\begin{array}{l}\text { Activity is strongly favourably and } \\
\text { its dominance is demonstrated in } \\
\text { practice }\end{array}$ & 7 \\
\hline $\begin{array}{l}\text { Extremely important } \\
\text { or more preferred }\end{array}$ & $\begin{array}{l}\text { Evidence favouring one activity } \\
\text { over the other is the greatest } \\
\text { possible in order affirmation }\end{array}$ & 9 \\
\hline Intermediate values & $\begin{array}{l}\text { Expressive identification between } \\
\text { two basic values of the scale }\end{array}$ & $2,4,6,8$ \\
\hline
\end{tabular}

Table $\mathrm{V}$ shows the matrix of relationships between different criteria in the presented case study of multi-criteria selection of the project implementation the enterprise management system (relationships are assessed by the decision-maker). Vector the matrix of domination of criteria allows the estimation of the relative importance of each criterion in relation to the overall objective, which is to maintain the competitiveness of the company.

TABLE V.

MATRIX EVALUATION CRITERIA

\begin{tabular}{|l|c|c|c|c|}
\hline Criteria & Efficiency & $\begin{array}{l}\text { Business } \\
\text { support }\end{array}$ & $\begin{array}{l}\text { Future } \\
\text { importance }\end{array}$ & $\begin{array}{l}\text { Technological } \\
\text { risk }\end{array}$ \\
\hline Efficiency & 1 & $1 / 5$ & $1 / 7$ & 3 \\
\hline $\begin{array}{l}\text { Business } \\
\text { support }\end{array}$ & 5 & 1 & $1 / 3$ & 5 \\
\hline
\end{tabular}




\begin{tabular}{|l|c|c|c|c|}
\hline $\begin{array}{l}\text { Future } \\
\text { importance }\end{array}$ & 7 & 3 & 1 & 7 \\
\hline $\begin{array}{l}\text { Technological } \\
\text { risk }\end{array}$ & $1 / 3$ & $1 / 5$ & $1 / 7$ & 1 \\
\hline Inconsistency $=0.09$ \\
\hline Scale vector & 0.092 & 0.282 & 0.574 & 0.052 \\
\hline
\end{tabular}

Next the matrices of evaluations for alternative projects were built (Table VI).

TABLE VI.

MATRicEs OF EVALUATION ALTERNATIVE PROJECTS (P1, P2, P3)

\begin{tabular}{|c|c|c|c|}
\hline Efficiency & P1 & P2 & P3 \\
\hline P1 & 1 & 3 & 5 \\
\hline P2 & $1 / 3$ & 1 & 3 \\
\hline P3 & $1 / 5$ & $1 / 3$ & 1 \\
\hline \multicolumn{2}{|l}{ Inconsistency $=0.04$} \\
\hline
\end{tabular}

\begin{tabular}{|c|c|c|c|}
\hline $\begin{array}{l}\text { Business } \\
\text { support }\end{array}$ & P1 & P2 & P3 \\
\hline P1 & 1 & $1 / 5$ & 3 \\
\hline P2 & 5 & 1 & 7 \\
\hline P3 & $1 / 3$ & $1 / 7$ & 1 \\
\hline \multicolumn{2}{|l}{ Inconsistency $=0.06$} \\
\hline
\end{tabular}

\begin{tabular}{|c|c|c|c|}
\hline $\begin{array}{l}\text { Future } \\
\text { importance }\end{array}$ & P1 & P2 & P3 \\
\hline P1 & 1 & $1 / 9$ & $1 / 7$ \\
\hline P2 & 9 & 1 & 3 \\
\hline P3 & 7 & $1 / 3$ & 1 \\
\hline \multicolumn{2}{|l|}{ Inconsistency $=0.08$} \\
\hline
\end{tabular}

\begin{tabular}{|c|c|c|c|}
\hline $\begin{array}{l}\text { Technological } \\
\text { risk }\end{array}$ & P1 & P2 & P3 \\
\hline P1 & 1 & 3 & 7 \\
\hline P2 & 1 & 1 & 5 \\
\hline P3 & $1 / 7$ & $1 / 5$ & 1 \\
\hline
\end{tabular}

Finally the evaluation of each project according to each criteria was summarized.

TABLE VII

EVALUATION OF PROJECTS

\begin{tabular}{|c|c|c|c|c|c|}
\hline \multirow[b]{2}{*}{ 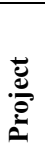 } & \multicolumn{4}{|c|}{ Criteria } & \multirow{2}{*}{ 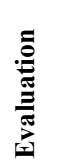 } \\
\hline & Efficiency & $\begin{array}{l}\text { Business } \\
\text { support }\end{array}$ & $\begin{array}{l}\text { Future } \\
\text { importance }\end{array}$ & $\begin{array}{l}\text { Technological } \\
\text { risk }\end{array}$ & \\
\hline P1 & 0.637 & 0.188 & 0.055 & 0.649 & 0.178 \\
\hline $\mathrm{P} 2$ & 0.258 & 0.731 & 0.655 & 0.279 & 0.616 \\
\hline P3 & 0.105 & 0.081 & 0.290 & 0.072 & 0.206 \\
\hline
\end{tabular}

Inconsistency $=0.08$

The overall rating of projects allows to establish the ranking of solutions P2, P3, P1 (Table VII). Project P2 has been rated highest, it has a significant advantage over alternative projects $\mathrm{P} 3$ and $\mathrm{P} 1$. According to the assessment using multi-criteria AHP method, the company should implement a management IT system using the offer of organization which has presented project $\mathrm{P} 2$.

The final decision about project execution can be based on some complex method of project evaluation or on project efficiency. Previously discussed feasibility study can include elements specified in chapter IV, at least as followed: technology and system feasibility, economic feasibility, legal feasibility, operational feasibility, schedule feasibility.

Considering which method of projects assessment to choose when we need to choose one IT project among several projects, or deciding to start a new IT project it should be noted that a complex assessment methods of projects evaluation helps us choose the best project among several alternative projects. While the feasibility study of the project is a detailed and comprehensive analysis of a specific project. Developing such a document is expensive and usually it is performed for one project only. In this case study AHP method allows you to choose the best variant of the project. The final decision on the project can be taken on the basis of this analysis. However, you can perform a feasibility study for project P2. Although the feasibility study of the project is costly, it gives us more certainty that the implementation of the project will bring the company the desired results and will be successful.

\section{BUSINESS PLAN}

\section{A. Description of the method}

Business plan is defined as:

- a plan of launching a business or as an action plan and development of the company; it is a special case of economic plan [31];

- a set of document developed by entrepreneur during preparation process of launching of the new project, showing its strategy and structure [32];

- a description method of a business and evaluation of the prospect of execution [4].

Business plan of the project is a study of the planned economic project which contains: purpose of analysis; circumstances of implementation; assessment of the advisability, feasibility and effectiveness evaluation. Business plan can be used for comprehensive evaluation of projects of small range and complexity [4].

Business plan refers to both results and costs and it shows project as a product market intended for potential customers. Business plan contains: objectives, impacts and process of the project.

Business plan is characterized by [4]:

- specificity - business plan must include: detail information of the: market, enterprise, project and planned actions,

- comprehensiveness - business plan must include all aspects of the planned activities (market, technical, personnel, organizational and financial activities),

- long-term effect - business plan is mostly a long-term plan, rarely annual.

Structure of the business plan depends on its purpose. General scheme of business plan includes four elements: general information - abstract, market conditioning of the project, operation conditioning of the project, assessment of the project's consequences (Table VIII; [33]).

TABLE VIII.

GENERAL SCHEME OF BUSINESS PLAN

\begin{tabular}{|r|l|}
\hline No. & \multicolumn{1}{c|}{ Description of the item } \\
\hline 1 & \multicolumn{1}{c|}{\begin{tabular}{c}
\multicolumn{1}{c|}{ General information } \\
- front page and table of contents \\
- subject of the business plan \\
- basic information \\
- performer of business plan \\
- current events and approvals \\
Abstract
\end{tabular}} \\
\hline 2 & $\begin{array}{l}\text { Market conditioning of the project } \\
\text { - users and sponsors of the project } \\
\text { - stakeholders of the project }\end{array}$ \\
\hline
\end{tabular}




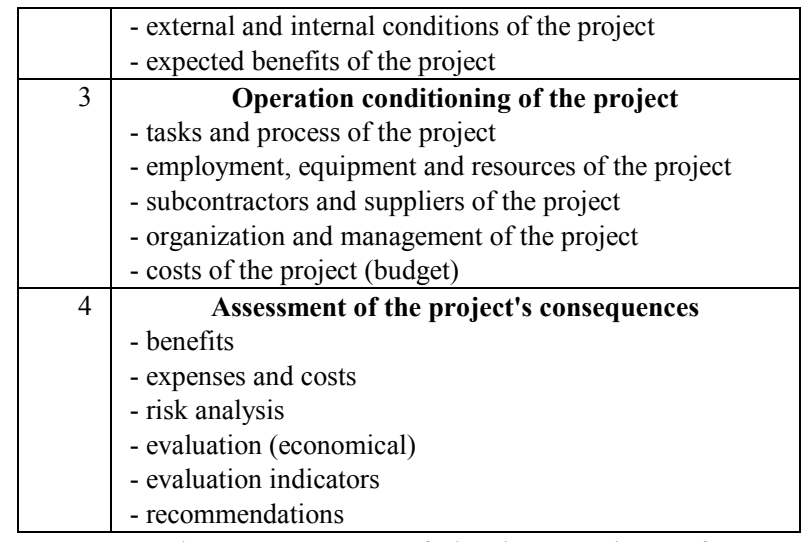

An exemplary structure of business plan of venture investment is presented in Table IX.

TABLE IX.

AN EXEMPLARY STRUCTURE OF BUSINESS PLAN OF VENTURE INVESTMENT EVALUATION CRITERIA

\begin{tabular}{|r|c|}
\hline \multicolumn{1}{|c|}{ No. } & Chapter \\
\hline 1 & Abstract \\
\hline 2 & General information about project \\
\hline 3 & Planned location of the investment \\
\hline 4 & Market analysis \\
\hline 5 & Competetive analysis \\
\hline 6 & Marketing strategy \\
\hline 7 & Technology of production \\
\hline 8 & Costs of production \\
\hline 9 & Organizational plan \\
\hline 10 & Project schedule \\
\hline 11 & Project budget \\
\hline 12 & The financial part \\
\hline 13 & Summary \\
\hline
\end{tabular}

Business plan of the project starts with an abstract in which the most important conclusions and a summary of entire plan should be included. This part of the plan should be designed very carefully as it is always read in detail during pre-selections of the projects.

Second chapter should contain basic information about the project: name of the project, information about participants, localization and information about lead organization.

Actual state supply, state demand and actual prices of product or services on the market are shown in the market analysis. This part of analysis is, in most cases, based on forecasts as investment can be realized in a new sector.

The fifth chapter gives information about main market competitors by analyzing their strengths and weaknesses. The marketing strategy includes main components of market activity such as: product, prices, distribution and promotions and can be found in chapter number six.

In a description of technology of production main steps of technological process and evaluation of its modernity should be characterized. Technology of production can be original investor's solution or a typical solution. This chapter should also include environmental legislation and information about certificates and licenses acquisition.

Determination of equipment's life time, development of modernization plan and repair plan are also necessary. Production is seasonal in many types of business therefore, the business plan should answer the question on how seasonality affects financial results (incomes and expenses). Chapter number eight covers estimation of production's costs or service delivery.

Organizational plan determines how the investment will be managed in the implementation phase and in the operational phase. Organizational scheme is presented in the chapter which shows work division and presents organization of key functions, like: supply, production and distribution.

Investment implementation schedule is described in chapter number ten. It should include all main investment tasks with the assume time of their implementation.

Detailed budget project should be developed in 11th chapter.

Economic and financial analysis is based on the financial plan and contains financial evaluation, profitability evaluation and risk assessment.

The most important data and conclusions are included in the last chapter.

Responsibility problem is associated with evaluation of the business plan. Business plan is used mainly for certain decision-making which results in specific measurable amount of expenses. Comprehensiveness is the most important advantage of business plan. Significant disadvantages include statistics and descriptive form of business plan.

\section{B. Reference to project efficiency}

If a long term calculation is assumed, every project can be consider as effective. Therefore, more precise definition of efficiency is the ratio investment results in a specific period of restoration capital time to investment's expenditures.

The investment efficiency account is a very important part of business plan which can be determine in a pre-investment phase (ex ante effectiveness account) and in operational phase (ex post effectiveness account). An ex ante effectiveness account is more important, from the point of view of business plan preparation, as it is a basis for investment decisions.

Assessment of investment effectiveness is carried out with the use of several tools which include:

- statistical methods for assessing the effectiveness of investment: payback investment rate, payback/return period,

- dynamical methods for assessing the effectiveness of investment: updated net value, discounted payback investment rate, discounted payback/return period, internal rate of interest.

Simpler statistical methods do not include variable time value of money which is why these methods are accounted as less useful.

The last element of the economic and financial analysis of the project is financial risk assessment of investment. Projects that are financially viable may be financially too risky to be selected for implementation. Risk covers many 
types of risks, including: the risk of contract, the risk of supply, investment risk, financial risk, credit risk, operational risk, transportation risk, insurance risk, price risk, currency risk and inflation risk.

Each business plan contains many assumptions about investment, costs, prices, demand, inflation etc. Effectiveness of planned investment is determined under assumptions which do not have to be confirm.

Investor who develops business plan should identify factors of financial risk and should also attempt to measure the risk. Financial risk can be measure by following methods: the scenario method, sensitivity analysis, analysis of the breakeven point.

Final evaluation of business plan comprises four elements: assessment of formal correctness, assessment of methodological correctness, assessment of accepted data, formulated assumptions and accounting evaluation.

Common errors and data manipulation in business plans mostly rely on [31]: overpricing, costs reducing, skipping some expenditure and costs, the discount rate reducing, inflate production capacity, the need of current assets reducing, accepting unrealistic growth rates of production and sales.

Business plan usually consists of four elements (Fig. 1).

\begin{tabular}{|c|c|}
\hline $\begin{array}{c}\text { I } \\
\text { Informational part }\end{array}$ & $\begin{array}{c}\text { II } \\
\text { Market's part }\end{array}$ \\
\hline $\begin{array}{c}\text { III } \\
\text { Operational part - } \\
\text { Expenses and costs }\end{array}$ & $\begin{array}{c}\text { IV } \\
\text { Evaluation - comparison of } \\
\text { benefits and expenditures }\end{array}$ \\
\hline
\end{tabular}

Fig. 1 Business plan

First part, informational part presents subject of business plan, performers and basic data of the project. The second market's part contains internal and external benefits of the project. The third part determines tasks, employment and management styles of the project. The result of the third part is to determine expenditures and costs developed as a project budget. The last part of business plan is a comparison of benefits and expenditures of the project with the use of: cash flow statement, balance sheet, or income statement. Business plan assessment methods depend on needs.

\section{BUSINESS CASE AND COST BENEFIT ANALYSIS}

\section{A. Description of business case}

Business case is a document prepared usually in organization which performs the project for its own needs. It may be prepared for every project, to support its planning and decision-taking. It is a method of assessing the business benefits of analysed project. During the project performance this method is used to analyse the impact of obtained partial results on expected business benefits. Analyses used in business cases are mainly of quantitative nature.

Based on estimated costs, benefits and savings as well as risks, $\mathrm{BC}$ involves all changes in business area which the project affects and description of the causes of the undertaking.

In practice it is mostly used in the ICT sector (where all benefits from implementation of information systems are necessary) and sporadically for social projects, although e.g. in Great Britain this document is obligatory for all projects undertaken by public entities.

The following types of business case are singled out [4]: strategic business case - general document indicating the relations between the project and organization strategy, full business case - document containing detailed plans of project performance and cost benefit analyses, ongoing business case - document precisely determining the inputs on works (usually within the nearest stage of the project).

BC does not have any strictly defined and mandatory structure, as it depends on the project specificity, i.e. its duration, budget, branch in which the employer is functioning etc. M. Trocki [2] repeats (after Taschner) that $\mathrm{BC}$ should consist of eight parts presented in Table X.

$\mathrm{BC}$ is one of the fundamental terms in PRINCE2. It plays a strategic role in the project assessment process, because it is assumed that the undertaking may last as long as this document gives affirmative answers to questions about the need, feasibility, profitability and cost-effectiveness of investing into the project.

It is an element of documentation which initiated the project. It gives rise to the decision to start, continue, interrupt or completely withdraw from the project. BC is being updated throughout the project life cycle [3]-[11].

$\mathrm{BC}$ consists of two documents:

1. Outline of the business case (introduction and basic information about the project: title of the project and possibly subtitle, author of the document and its recipient, date of the document preparation and submission, generally determined $\mathrm{BC}$ area, defined goals of the project, purpose of $\mathrm{BC}$ preparation).

2. Detailed business case (DBC) - its most important element is assessment of the project cost-effectiveness.

A very important element of DBC is definition of the pattern according to which the project implementation variants will be described, because $\mathrm{BC}$ should contain a description of several possible methods of achieving the same goal. The indicated methods should enable a comparison of the variants of this undertaking [5].

The basic element of DBC is presentation of possible variants of the project performance. Each of the variants requires a detailed feasibility study [6].

According to the PRINCE2 (2009) method the project requires first of all focussing on business aspects starting from the reasons for which it was launched till it was closed [10]. 
TABLE X.

PARTS OF BUSINESS CASE

\begin{tabular}{|c|c|}
\hline Part name & Description \\
\hline $\begin{array}{l}\text { Macroeconomic } \\
\text { part }\end{array}$ & $\begin{array}{l}\text { It comprises the most important macroeconomic } \\
\text { information influencing the project, subjecting it } \\
\text { to analysis and formulating conclusions }\end{array}$ \\
\hline Tax-related part & $\begin{array}{l}\text { It contains tax analyses necessary for assessment } \\
\text { of the project }\end{array}$ \\
\hline Financial part & $\begin{array}{l}\text { It involves determination of the project financial } \\
\text { needs, indicating and choice of financing sources } \\
\text { and preparing the cash flow plans }\end{array}$ \\
\hline Market part & $\begin{array}{l}\text { Market analyses connected with the result and } \\
\text { conditions of its market performance }\end{array}$ \\
\hline Marketing part & $\begin{array}{l}\text { Market analyses are the starting point for } \\
\text { marketing surveys determining market effects of } \\
\text { project implementation }\end{array}$ \\
\hline Operational part & $\begin{array}{l}\text { It describes technical conditions of project } \\
\text { implementation and its effects }\end{array}$ \\
\hline Investment part & $\begin{array}{l}\text { Information from all parts is focused in } \\
\text { investment part, where the project's financial } \\
\text { assessment is made, using the investment } \\
\text { efficiency account method }\end{array}$ \\
\hline $\mathrm{BC}$ results & $\begin{array}{l}\text { Each BC should refer to free and comprehensive } \\
\text { decisions consisting of the choice from at least } \\
\text { two alternatives; the decision consequences } \\
\text { should wholly or largely be expressed in } \\
\text { monetary units; importance of the decision } \\
\text { consequences should determine the inputs on BC; } \\
\text { The last part of BC should contain: a short } \\
\text { summing up of the project goals, expected } \\
\text { benefits, necessary inputs, the most important } \\
\text { risks and list of recommendations related to the } \\
\text { project implementation formula }\end{array}$ \\
\hline
\end{tabular}

The main and obligatory element of business case is a list of expected benefits and optional components of the cost benefit analysis and assessment of investment.

\section{B. Description of cost benefit analysis}

Cost benefit analysis (CBA) consists in determining and comparing the expected costs and benefits from variants of the project to choose the best and most profitable variant.

The cost benefit analysis usually consists of the following parts [7]-[12]-[13]: identification of the project, defining the goals, feasibility study, economic analysis, multi-criterial analysis, other criteria of evaluation, sensitivity analysis and risk evaluation.

The results of the cost benefit analysis are often presented in the so called cost-benefit matrix [12] (Fig. 2).

The projects placed - in result of analysis - in area I usually are not referred to performance. The possibility to perform the area II projects (they lead to significant benefits but simultaneously require quite high inputs) is limited, because they require special conditions to be performed, e.g. foundation of consortia, special companies etc. The area III projects are considered to be dangerous because of the temptation to implement them which resulted from low costs. However, they do not provide sufficient benefits, therefore other performance variants should be taken into account. Most demanded is the performance of area IV projects because these are most advantageous.

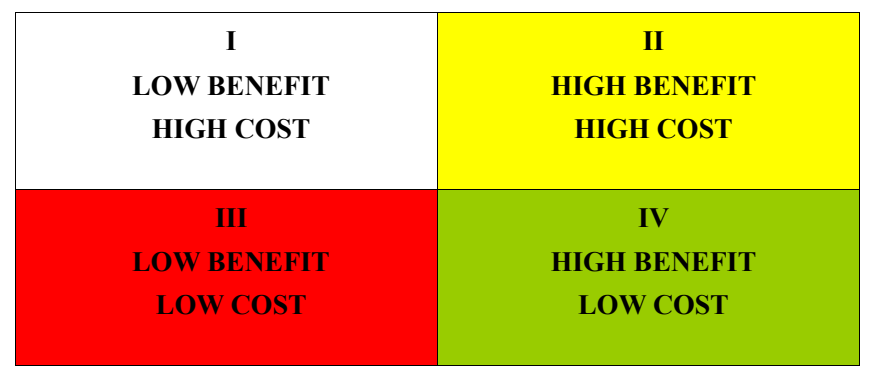

Fig. 2 Cost-Benefit Matrix

Business case usually supports taking of investment decisions i.e. the situations where decisions are made about alternative possibilities of using financial means in the project. Owing to $\mathrm{BC}$ at least the financial consequences of those decisions may be analysed, but also their non-financial effects may be considered. So BC is a practical use of the investment efficiency account in project management.

Assessment of the project cost-effectiveness as the most important component of DBC in PRINCE2 comprises analysis of joint benefits and adverse effects with the project performance costs and future maintenance of its final products. For the financial part PRINCE2 recommends here: analyses of complete costs and benefits, net costs and products. Recommended for the financial part of PRINCE2 are: analyses of total costs and benefits, net costs and benefits, return on investment, simple payback period, discounted methods, current net value or analysis of project sensitivity to disturbances.

The CBA part involving the financial analysis should show the project profitability and its financial sustainability by solving the following problems: choice of the time horizon, determination of total inputs and incomes, calculation of residual value at the end of the year, determination of the inflation factor, choice of an appropriate discount rate, financial calculation or economic rate of return and the method of using those indices in project assessment. The project effects prognosis should be made for its performance time and the period allowing to show its effects in close and further perspective.

During economic analysis carried out at CBA the costs and notable socio-economic benefits of the project are determined. If it is possible, the benefits for external environment should be expressed in monetary units, Otherwise, ascribed to those benefits should be an appropriate numerical value enabling to bring them down to rational values. Both all the costs and social benefits expected for various years should be discounted to the basic year value or using a harmonized discount rate for a given sector of economy or region. An alternative approach is calculation of internal economic rate of return or economic current net value. 
TABLE XI.

SIMPLIFIED BUSINESS CASE FOR THE PROJECT A WITH COST BENEFIT ANALYSIS AND INVESTMENT APPRAISAL

\begin{tabular}{|l|c|c|c|c|c|c|c|}
\hline YEAR & 0 & 1 & 2 & 3 & 4 & 5 & VALUES \\
\hline Costs (in thousands of PLN) & -100 & -20 & -20 & -20 & -40 & -30 & \\
\hline Benefits (in thousands of PLN) & 0 & 40 & 80 & 100 & 100 & 100 & \\
\hline $\begin{array}{l}\text { Cash flow (in thousands of } \\
\text { PLN) }\end{array}$ & -100 & 20 & 60 & 80 & 60 & 70 & $\mathbf{5 8}$ \\
\hline $\begin{array}{l}\text { Cumulative cash flow (in } \\
\text { thousands of PLN) }\end{array}$ & -100 & -80 & -20 & 60 & 120 & 190 & \\
\hline Discount ratio & 1.00 & 0.94 & 0.88 & 0.83 & 0.78 & 0.74 & \\
\hline $\begin{array}{l}\text { Cash flow after discounting } \\
\text { (rounded up to thousands of } \\
\text { PLN) }\end{array}$ & -100 & 19 & 53 & 66 & 47 & 52 & $\Sigma \boldsymbol{C F}_{\boldsymbol{t}}=\mathbf{2 3 7}$ \\
\hline $\begin{array}{l}\text { Cumulative cash flow after } \\
\text { discounting (in thousands of } \\
\text { PLN) }\end{array}$ & -100 & -81 & -28 & 38 & 85 & 137 & $\mathbf{N P V}=\mathbf{1 3 7}$ \\
\hline
\end{tabular}

\section{Case study}

Let us consider two investment projects: project $\mathrm{A}$ and project B. Both have identical performance time reaching 5 years and identical investment inputs amounting to 100000 PLN. In the case of project A the following fluxes of financial surpluses (CF) are forecast: at the end of the first year -20000 PLN, the second year -60000 , the third year -80000 , the fourth year -60000 and the fifth year 70000 PLN (line 3 in Table IV). In project B the forecast financial surpluses at the end of each of the periods are identical and amount to 58000 PLN.

Simplified BC including the cost benefit analysis and investment assessment is presented for project $\mathrm{A}$ in Table XI, whereas for project B in Table XII.

Actually, introduced to pattern $\mathrm{BC}$ are all costs (the first lines in Table XI and Table XII) with tangible benefits (the second lines in these tables), which gives cash flows for the projects (the third lines), equal to benefits (incomes) decreased by costs.

The cost benefit analysis is aimed at discerning the moment when the first incomes from the project appeared. They are then assessed using a discount rate. In the fifth line for each period the discount ratio is calculated. The assumed (in these examples) rate of return within a year is $6.3 \%$ for every project.
The discount ratio for a given period is treated similarly as weight while counting the weighted average, except that in the NPV case it is the ,weighted total”. Pursuant to this premise, a further stage is discounting of cash flows (the sixth lines in Table XI and Table XII) by multiplying the value of cash flows from a given period (the third line) by the value of the discount ratio (the fifth line). Subsequently, at the intersection of the sixth line and the seventh column the total of discounted cash flows is calculated $\left(\sum \mathrm{CF}_{\mathrm{t}}\right)$.

On the other hand, the aim of the whole investment is to determine the NPV value, otherwise called the updated net value or the present net value. NPV is a method of assessment of the tangible investment economic efficiency but also an indicator determined according to this method.

In the present situation, NPV is considered as an indicator constituting a difference between the sum of discounted cash flows and initial inputs.

It is assumed that the investment should pay for itself in the period not longer than 2 years. The period of return on inputs in the case of project A amounts to 2.4 years, and in the case of project B it reaches 1,9 years. The calculations used the formula in which inputs are compared with cumulated positive cash flows and then we should observe when the sum is zero. Project B is better than project A, because it provides a faster return on inputs and does not

TABLE XII.

SIMPLIFIED BUSINESS CASE FOR THE PROJECT B WITH COST BENEFIT ANALYSIS AND INVESTMENT APPRAISAL

\begin{tabular}{|c|c|c|c|c|c|c|c|}
\hline YEAR & 0 & 1 & 2 & 3 & 4 & 5 & VALUES \\
\hline Costs (in thousands of PLN) & -100 & -20 & -20 & -20 & -40 & -30 & \\
\hline Benefits (in thousands of PLN) & 0 & 78 & 78 & 78 & 98 & 88 & \\
\hline $\begin{array}{l}\text { Cash flow (in thousands of } \\
\text { PLN) }\end{array}$ & -100 & 58 & 58 & 58 & 58 & 58 & 58 \\
\hline $\begin{array}{l}\text { Cumulative cash flow (in } \\
\text { thousands of PLN) }\end{array}$ & -100 & -42 & 16 & 74 & 132 & 190 & \\
\hline Discount ratio & 1 & 0.94 & 0.88 & 0.83 & 0.78 & 0.74 & \\
\hline $\begin{array}{l}\text { Cash flow after discounting } \\
\text { (rounded up to thousands of } \\
\text { PLN) }\end{array}$ & -100 & 55 & 51 & 48 & 45 & 43 & $\sum C F_{t}=242$ \\
\hline $\begin{array}{l}\text { Cumulative cash flow after } \\
\text { discounting (in thousands of } \\
\text { PLN) }\end{array}$ & -100 & -45 & 6 & 54 & 99 & 142 & $\mathrm{NPV}=142$ \\
\hline
\end{tabular}


exceed the assumed two-years' period of the investment payback.

NPV for project A amounts to 137000 PLN, and for project B - 142000 PLN (intersection of the seventh line and the seventh column in Table XI and Table XII). In NPV we accept only projects with NPV higher than zero, and we reject the other ones. The decision about the choice of a specific project is correct for the specified interest rate.

Of the two projects excluding each other we choose the project with a higher NPV. In the given case it is project B which not only provides a faster return of inputs but it also provides an additional surplus of 142000 PLN.

Implementation of business case in organization changes the way of thinking about project initiatives, because it requires explicit defining of profits from performance of the undertaking. Problems with indicating the profits or inability to measure the profits demonstrate that the suggested project has significant drawbacks.

An important advantage of the use of $\mathrm{BC}$ is the necessity to prepare some variants of the project performance, which gives the organization's managers more decision-making possibilities e.g. as to alternative investment methods. On the other hand, the need to include many complex aspects constitutes the greatest drawback of this document.

\section{REFERENCES}

[1] W. Rogowski, "Współczesny rachunek efektywności projektów ujęcie problemowe", in Ocena projektów - koncepcje i metody, M. Trocki, M. Juchniewicz, Ed. Warsaw: Szkoła Głowna Handlowa w Warszawie - Oficyna Wydawnicza, 2013, pp. 43-76.

[2] M. Trocki, "Kompleksowe metody oceny projektów", in Nowoczesne zarządzanie projektami, M. Trocki, Ed. Warsaw: Polskie Wydawnictwo Ekonomiczne, 2012, pp. 280-295.

[3] Managing Successful Projects with PRINCE2, TSO (The Stationery Office), London: 2009.

[4] M. Juchniewicz, M. Trocki, "Metody oceny projektów", in Ocena projektów - koncepcje i metody, M. Trocki, M. Juchniewicz, Ed. Warsaw: Szkoła Głowna Handlowa w Warszawie - Oficyna Wydawnicza, 2013, pp. 207-211, pp. 201-202, pp. 196-202.

[5] J. Ward, E. Daniel, J. Peppard, "Building Better Business Case for IT Investments", MIS Quarterly Executive, vol. 7, no. 1, 2008, pp.1-15.

[6] M. J. Schmidt, The IT Business Case: Key to Accuracy and Credibility, Solution Matrix Ltd., Boston: 2008.

[7] H. Smith, J. McKeen; C. Cranston; M. Benson, "Investment Spend Optimization: A New Approach to IT Investment at BMO Financial Group", MIS Quarterly Executive, vol. 9, no. 2, 2010.

[8] E. Sońta-Drączkowska, Zarządzanie wieloma projektami. Warsaw: Polskie Wydawnictwo Ekonomiczne, 2012, pp. 7-87, 104-141.

[9] M. Trocki, "Wprowadzenie do problematyki oceny projektów", in Ocena projektów - koncepcje i metody, M. Trocki, M. Juchniewicz,
Ed. Warsaw: Szkoła Głowna Handlowa w Warszawie - Oficyna Wydawnicza, 2013, pp. 9-16.

[10] P. Wyrozębski, "Metodyka PRINCE2®", in Metodyki zarządzania projektami, M. Trocki, Ed. Warszawa: Bizarre, 2011, pp. 95-122.

[11] A. Kaczorowska, E-usługi administracji publicznej w warunkach zarządzania projektami. Łódź: Wydawnictwo Uniwersytetu Łódzkiego, 2013.

[12] W. W. Sofko, The Role of Cost-Benefit Analysis in Achieving Results nin Special Education, Retrieved April, 05,2016 from http://www.wildwoodinstitute.org/knowledge/results.html

[13] T. Melton, P. Iles-Smith, J. Yates, Project Benefits Management. Linking Projects to the Business. Elsevier, 2008.

[14] W. Rogowski, Rachunek efektywności przedsięwzięć inwestycyjnych. Kraków: Oficyna Ekonomiczna, 2004

[15] T. J. Kloppenborg, Project Management: A Contemporary Approach. CA: South-Western Cengage Learning, 2009, pp. 34-50.

[16] O. Nadskakuła, Ewaluacja projektów. Warsaw: Bizarre, 2009.

[17] P. Harper-Smith, S. Derby, Fast Track to Success Project Management. Edinburgh: Pearson Education Limited, 2009, p. 205.

[18] S. E. Portny, Zarządzanie projektami dla bystrzaków. Gliwice: Helion, 2013, p. 46.

[19] W. Dow, PMP, B. Taylor, Project Management Communication Bible. Indianapolis: Wiley Publishing, 2008, pp. 132-136, 491-494.

[20] R. K. Wysocki, R. Mcgary, Efektywne zarządzanie projektami. Gliwice: Helion, 2005, p. 112.

[21] M. Trocki, E. Bukłaha, B. Grucza, P. Wyrozębski, M. Juchniewicz, and W. Metelski, Nowoczesne zarządzanie projektami. M. Trocki, Ed. Warsaw: Polskie Wydawnictwo Ekonomiczne, 2012, pp. 280-284.

[22] R. Newton, The Practice and Theory of Project Management. New York: Palgrave Macmillan, 2009, pp. 21, 93-94.

[23] J. Phillips, Zarządzanie projektami IT. Helion, Gliwice, 2011, pp. 64-71.

[24] T. Kasprzak, Biznes i technologie informacyjne. Perspektywa integracji strategicznej. Warsaw: Katedra Informatyki Gospodarczej I Analiz Ekonomicznych UW, 2003.

[25] G. Serefeimidis, "A Review of Research Issues in Evaluation of Information Systems", in Information Technology Evaluation Methods and Management, W. V. Grembergen, Ed. London: Idea Group Publishing, 2001, DOI: 10.4018/978-1-878289-90-2.ch004.

[26] M. Nowak, T. Błaszczyk, B. Nowak, K. Targiel, Wspomaganie decyzji w planowaniu projektów. Warsaw: Difin, 2014, pp.82-136.

[27] C. Pineiro Sanchez, "Aplicaciones de la teoria de la decision multicriterio", in Revista Gallega de Economia, vol. 12, no. 1, 2003, pp. 105-122.

[28] M. M. Parker, H. E. Trainor, R. J. Benson, Information Economics. Linking Business Performance to Information Technology. New Jersey: Prentice Hall, 1988, pp. 36-37.

[29] M. M. Parker, H. E. Trainor, R. J. Benson, Information Strategy and Economics. New Jersey: Prentice Hall, 1989.

[30] T. L. Saaty, "Priority Setting in Complex Problems", in IEEE Transaction of Engineering Management, vol. EM 30, no. 3, 1983, pp. 140-155, DOI: 10.1109/TEM.1983.6448606.

[31] Z. Pawlak, Biznesplan zastosowania i przykłady. Warsaw: Oficyna Wydawnicza WSEiZ w Warszawie, 1999, pp. 196-200.

[32] R. W. Griffin, Podstawy zarządzania organizacjami. Warsaw: Wydawnictwo Naukowe PWN, 2004.

[33] M. Trocki, E. Bukłaha, B. Grucza, M. Juchniewicz, W. Metelski, and P. Wyrozębski, Nowoczesne zarządzanie projektami. M. Trocki, Ed. Warsaw: Polskie Wydawnictwo Ekonomiczne, 2012, p. 285. 